\title{
Synthesis of 5-Methyluridine by a Thermophile, Bacillus stearothermophilus JTS 859
}

\author{
Nobuaki HORI, Mutsumi WATANABE, Yoshinari YAMAZAKI \\ and Yoichi MIKAMI
}

Tobacco Science Research Laboratory, Japan Tobacco Inc., 6-2 Umegaoka, Midori-ku, Yokohama 227, Japan

Received August 10, 1988

\begin{abstract}
Many thermophiles, which can grow at $65^{\circ} \mathrm{C}$, were examined as to their ability to produce 5methyluridine from inosine and thymine (5-methyluracil) in the presence of phosphate and cells as enzyme sources. Bacillus stearothermophilus JTS 859 was selected as a strain that synthesized 5methyluridine efficiently. The reaction is supposed to be carried out by a combination of a thermostable purine nucleoside phosphorylase and a thermostable pyrimidine nucleoside phosphorylase. Their halflives were $7200 \mathrm{hr}$ and $400 \mathrm{hr}$ at $63^{\circ} \mathrm{C}$, and $148 \mathrm{hr}$ and $14 \mathrm{hr}$ at $70^{\circ} \mathrm{C}$, respectively.
\end{abstract}

Nucleosides such as inosine, adenosine, uridine and cytidine are produced by a fermentation method, but thymidine has not been produced by such a method. Thymidine is practically produced by hydrolysis and separation from deoxyribonucleic acid derived from natural sources such as milt. As an alternative to this method, we developed a method for the practical production of thymidine from non-natural sources. We tried to synthesize 5-methyluridine (5MU) from thymine (5-methyluracil) and inosine enzymatically at first by means of the ribosyl transfer reaction, as shown in the following chemical equations, and to chemically reduce the hydroxy group at the 2'-position on the ribose ring of $5 \mathrm{MU}$ to yield thymidine.

$$
\begin{aligned}
& \text { Inosine }+ \text { Phosphate } \rightarrow \\
& \text { Ribose-1-phosphate }+ \text { Hypoxanthine } \\
& \text { Ribose-1-phosphate }+ \text { Thymine } \rightarrow \\
& \text { 5-Methyluridine }+ \text { Phosphate }
\end{aligned}
$$

We selected inosine as a ribose donor because it it produced abundantly in industrial fermentations. This paper describes the synthesis of 5 methyluridine using thermostable enzymes produced by a thermophile.
The ribosyl transfer reaction has been studied for a long time. ${ }^{1 \sim 41}$ This reaction is carried out by purine nucleoside phosphorylase, pyrimidine nucleoside phosphorylase, uridine phosphorylase, thymidine phosphorylase and a combination of these enzymes. The substrate specificities of these enzymes are not strict, therefore, the ribosyl transfer reaction has been applied for the synthesis of nucleoside analogues, 5-fluorouridine, 5-bromouridine and so on. ${ }^{5 \sim 7}$ It is necessary that the enzymes used for practical application should be stable for a long time. Enzymes derived from mesophiles have been used for practical application. As for thermostable enzymes derived from thermophiles, only pyrimidine nucleoside phosphorylase from $B a$ cillus stearothermophilus NCA10 has been reported..$^{8)}$

The application of thermostable enzymes has several advantages. ${ }^{9)}$ The reaction can be carried out at high temperature for a long time and the reaction rate is also high. The higher solubility of the reactants allows operation with higher concentrations of reactants. The solubility of $5 \mathrm{MU}$ is $83 \mathrm{~g} / 1$ at $25^{\circ} \mathrm{C}$ and above $500 \mathrm{~g} / 1$ at $63^{\circ} \mathrm{C}$. Thermostable enzyme reactors are resistant to bacterial contamination due to the high operation temperature. This is impor- 
tant for practical application because usual enzyme reactors tend to be contaminated by bacteria.

As thermostable enzymes have these advantages, we screened thermophiles and finally found a thermophile, Bacillus stearothermophilus JTS 859 , that efficiently produced thermostable enzymes for the ribosyl transfer reaction. The thermal stabilities of these enzymes were high. The half-lives of the enzymes as to the formation of $5 \mathrm{MU}$ at $63^{\circ} \mathrm{C}$ and $70^{\circ} \mathrm{C}$ were $400 \mathrm{hr}$ and $14 \mathrm{hr}$, respectively.

\section{Materials and Methods}

Microorganisms. All strains used were isolated at $65^{\circ} \mathrm{C}$ from soil and sludge from hot springs and drains in Beppu, Houfu and Izu.

Chemicals. Thymine and inosine were purchased from Wako Pure Chemical Industries, Ltd. and Yamasa Shoyu Co., Ltd, respectively. All other reagents, of analytical grade, were commercially available.

Culture media. Medium A, containing ( $\mathrm{g} / 1$ of water) Bacto-Tryptone 10, Bacto-Yeast extract 5 , glucose 3 and $\mathrm{NaCl} 3$, was used for the cultivation of B. stearothermophilus JTS 859. Medium B used for screening was Medium A supplemented with pig liver infusion 25 and glycerol $18.9(\mathrm{~g} / \mathrm{l})$. The liver infusion was prepared as follows; sliced liver $(25 \mathrm{~g})$ was boiled gently in water $(150 \mathrm{ml})$ for $30 \mathrm{~min}$, followed by filtration through gause.

Screening. Cultivation was carried out in an Erlenmeyer flask $(500 \mathrm{ml})$ containing $100 \mathrm{ml}$ of medium $\mathrm{B}$ at $210 \mathrm{rpm}$ for 4 to $5 \mathrm{hr}$ at $63^{\circ} \mathrm{C}$. The cells were harvested by centrifugation $(10,000 \times g, 15 \mathrm{~min})$ and $500 \mathrm{mg}$ of wet cells was added to $10 \mathrm{ml}$ of reaction solution $\mathrm{A}$ or $\mathrm{B}$. Reaction solution A contained $20 \mathrm{~mm}$ inosine, $25 \mathrm{~mm}$ thymine, $60 \mathrm{~mm} \mathrm{KH} \mathrm{PO}_{4}, 50 \mathrm{~mm}$ Tris $\mathrm{HCl}$ and $11.1 \mathrm{~mm}$ glucose $(\mathrm{pH} \mathrm{7.0)}$. Reaction solution B contained $20 \mathrm{~mm}$ inosine, $20 \mathrm{~mm}$ thymine and $20 \mathrm{~mm}$ potassium phosphate $(\mathrm{pH} 7.0$ ). Each reaction mixture was incubated for $3 \mathrm{hr}$ at $65^{\circ} \mathrm{C}$. After the reaction mixture had been centrifuged to remove insoluble materials, the supernatant was analyzed for $5 \mathrm{MU}$.

Enzyme assay. The standard reaction mixture, consisting of $20 \mathrm{~mm}$ inosine, $20 \mathrm{~mm}$ thymine, $20 \mathrm{~mm}$ potassium phosphate $(\mathrm{pH} 7.0)$ and $50 \mu$ lof the crude enzyme solution in a total volume of $1.0 \mathrm{ml}$, was incubated at $60^{\circ} \mathrm{C}$ for $1 \mathrm{hr}$. Fifty $\mu$ of the reaction mixture was removed and added to $950 \mu \mathrm{l}$ of $\mathrm{MeOH}$ to terminate the reaction, followed by analysis by HPLC.

Analysis. Quantitative determination of bases and nucleosides was carried out HPLC. The operating conditions were as follows: column, Chemcosorb 5-ODS-H $(\phi 4 \times 300 \mathrm{~mm})($ Chemco Scientific Co., Ltd., Osaka); column temperature, $38^{\circ} \mathrm{C}$; solvent, water- $\mathrm{MeOH}=95: 5$ $(\mathrm{v} / \mathrm{v})$; flow rate, $0.8 \mathrm{ml} / \mathrm{min}$; detector, $\mathrm{UV}$ monitor (254 nm).

Ribose-1-phosphate was detected by HPLC. The operating conditions were as follows: column TSKgel DEAE-5PW, $(\phi 7.5 \times 75 \mathrm{~mm})$ (Tosoh Co. Tokyo); solvent, $50 \mathrm{~mm}$ potassium phosphate $(\mathrm{pH} 5.1)$; flow rate, $1 \mathrm{ml} / \mathrm{min}$; detector, $\mathrm{RI}$; retention time, $5.6 \mathrm{~min}$.

Preparation of crude enzymes. B. stearothermophilus JTS 859 was grown in a $500 \mathrm{ml}$ flask containing $100 \mathrm{ml}$ of medium $\mathrm{A}$ at $65^{\circ} \mathrm{C}$ for $4.5 \mathrm{hr}$ at $210 \mathrm{rpm}$. Cells were collected by centrifugation $\left(10,000 \times g, 10 \mathrm{~min}, 4^{\circ} \mathrm{C}\right)$. One gram of wet cells was suspended in $10 \mathrm{ml}$ of $20 \mathrm{~mm}$ potassium phosphate buffer $(\mathrm{pH} \mathrm{7.0)}$ and then disrupted with an ultrasonic oscillator for $10 \mathrm{~min}\left(20 \mathrm{kHz}, 0 \sim 10^{\circ} \mathrm{C}\right)$. After centrifiguation $\left(10,000 \times \mathrm{g}, 10 \mathrm{~min}, 4^{\circ} \mathrm{C}\right)$, the resultant supernatant, containing $15.1 \mathrm{mg} / \mathrm{ml}$ protein was used as the crude enzymes.

Preparation of acetone-treated crude enzymes. Eight $\mathrm{ml}$ of acetone $\left(-20^{\circ} \mathrm{C}\right)$ was added to $10 \mathrm{ml}$ of crude enzymes. After standing for $15 \mathrm{~min}$ below $5^{\circ} \mathrm{C}$, the mixture was centrifuged $\left(10,000 \times g, 10 \mathrm{~min}, 4^{\circ} \mathrm{C}\right)$. Six $\mathrm{ml}$ of acetone $\left(-20^{\circ} \mathrm{C}\right)$ was added to the supernatant. After standing for $15 \mathrm{~min}$ below $5^{\circ} \mathrm{C}$, the mixture was centrifuged $(10,000 \times g$, $10 \mathrm{~min}, 4^{\circ} \mathrm{C}$ ). The precipitate was dissolved in $5 \mathrm{ml}$ of $20 \mathrm{~mm}$ potassium phosphate buffer $(\mathrm{pH} \mathrm{7.0)}$ ). It contained $11.4 \mathrm{mg} / \mathrm{ml}$ protein and was used as the acetone-treated crude enzymes.

\section{Results}

\section{Screening}

Using $4 \mathrm{hr}$-cultured and $16 \mathrm{hr}$-cultured cells of various strains as enzyme sources, we examined the ability to form $5 \mathrm{MU}$ at $65^{\circ} \mathrm{C}$. One hundred and seventy thermophilic strains were investigated in the survey. None of the $16 \mathrm{hr}-$ cultured cells of the strains formed 5MU. As to $4 \mathrm{hr}$-cultured cells of the strains, 69 strains showed the enzymatic activity. Among them, 4 strains showed high ability as to $5 \mathrm{MU}$ formation (Table I). We selected JTS 859 isolated from sludge, as the most active strain per wet cell, for further investigation. 
Table I. Formation OF 5-MethyluRidine BY THE SeLected Thermophiles

The reaction was carried out as described in the text.

\begin{tabular}{lc}
\hline Strain & $\begin{array}{c}\text { 5-Methyluridine } \\
(\mu \mathrm{mol} / \mathrm{hr} \cdot \mathrm{g} \text { wet cell })\end{array}$ \\
\hline H-254 & 43 \\
JTS 859 & 105 \\
H-491 & 41 \\
H-524 & 39 \\
\hline
\end{tabular}

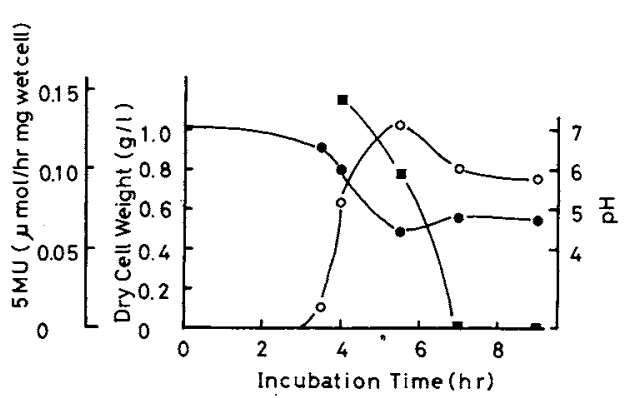

Fig. 1. Time Course of Culture.

Bacillus stearothermophilus JTS 859 was cultivated in Medium A at $65^{\circ} \mathrm{C}$. Ten $\mathrm{ml}$ of the reaction mixture, containing $200 \mathrm{mg}$ wet cells, $20 \mathrm{~mm}$ inosine, $20 \mathrm{~mm}$ thymine, $60 \mathrm{~mm}$ potassium phosphate and $11.1 \mathrm{~mm}$ glucose $\left(\mathrm{pH} 7.0\right.$ ), was incubated for $3 \mathrm{hr}$ at $65^{\circ} \mathrm{C}$. $\mathrm{O}$, dry cells;

$\mathrm{pH} ; \mathbf{\square}$, 5-methyluridine (5MU).

\section{Time course of the culture}

The enzymatic activity was measured with the cultivation time (Fig. 1). Cells grew rapidly from 3 to $5.5 \mathrm{hr}$ after inoculation. The enzymatic activity was high during the logarithmic phase of growth and had disappeared by $7 \mathrm{hr}$ after the inoculation. Thus, the harvesting time of this thermophile was important.

\section{Identification}

The JTS 859 strain was identified as Bacillus stearothermophilus based on its taxonomical properties, referring to Bergey's Manual of Systematic Bacteriology (Table II). ${ }^{10}$

\section{Isolation and identification of $5 \mathrm{MU}$ from the} reaction mixture

Four $\mathrm{ml}$ of the crude enzyme solution was added to $36 \mathrm{ml}$ of $20 \mathrm{~mm}$ potassium phosphate buffer ( $\mathrm{pH} 7.0$ ) containing $804 \mathrm{mg}$ ( $3 \mathrm{mmol}$ ) inosine and $378 \mathrm{mg}(3 \mathrm{mmol})$ thymine. The
Table II. TAXONOMICAL Properties of STRAin JTS-859

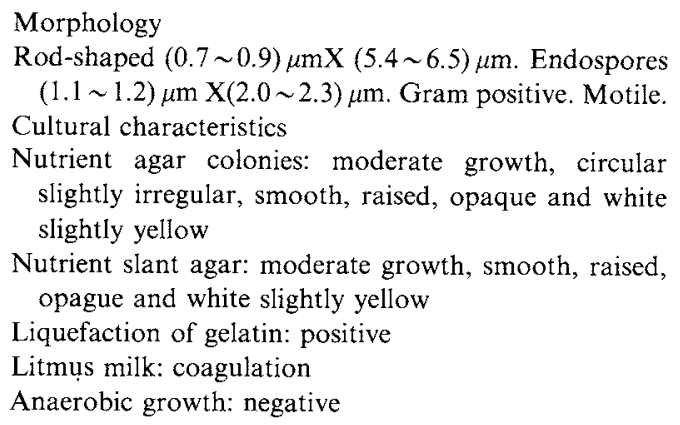

reaction was carried out for $16 \mathrm{hr}$ at $65^{\circ} \mathrm{C}$. The reaction mixture was applied on a column of Dowex 50WX $\left(\mathrm{H}^{+}\right.$form, $\left.100 \mathrm{ml}\right)$ and then elution was carried out with water $(300 \mathrm{ml})$. The eluate containing $5 \mathrm{MU}$ and thymine was obtained. $5 \mathrm{MU}$ was isolated from the eluate by HPLC (Licrosorb RP-18 $\phi 8 \times 250$ (Merck, Darmstadt), water-MeOH=97.5:2.5 (v/v), $4 \mathrm{ml} / \mathrm{min}$ ), $177.1 \mathrm{mg}$ of $5 \mathrm{MU}$ being obtained; NMR $\delta_{\mathrm{C}}\left(\mathrm{CD}_{3} \mathrm{OD}\right): 152.5(\mathrm{~s}, \mathrm{C}-2), 166.2(\mathrm{~s}, \mathrm{C}-$ 


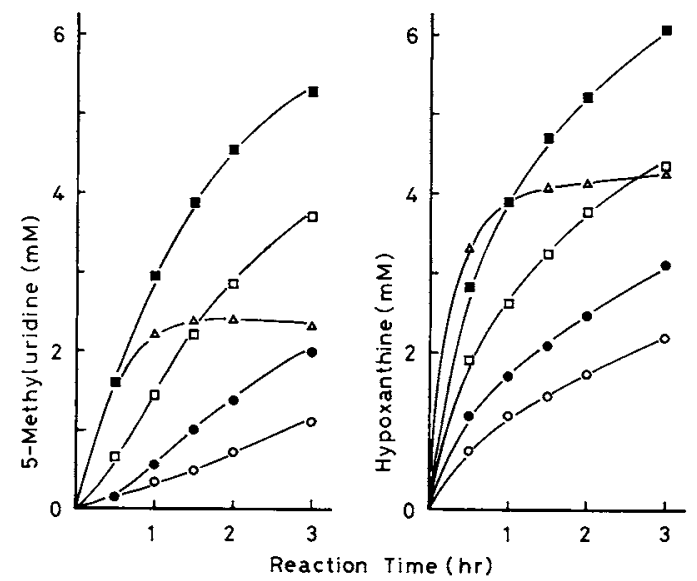

Fig. 2. Effect of Temperature.

Reaction mixtures containing $20 \mathrm{~mm}$ inosine, $20 \mathrm{~mm}$ thymine, $20 \mathrm{~mm}$ potassium phosphate and $50 \mu \mathrm{l}$ of crude enzymes in a total volume of $1 \mathrm{ml}$, were incubated at various temperatures. $\mathrm{O}, 40^{\circ} \mathrm{C} ; 0,50^{\circ} \mathrm{C} ; \square, 60^{\circ} \mathrm{C}$; $70^{\circ} \mathrm{C} ; \triangle 80^{\circ} \mathrm{C}$

4), $111.4(\mathrm{~s}, \mathrm{C}-5), 138.3(\mathrm{~d}, \mathrm{C}-6), 12.4(\mathrm{~g},-\mathrm{Me})$, $90.4\left(\mathrm{~d}, \mathrm{C}-\mathrm{I}^{\prime}\right), 75.4\left(\mathrm{~d}, \mathrm{C}-2^{\prime}\right), 71.3\left(\mathrm{~d}, \mathrm{C}-3^{\prime}\right)$, $86.2\left(\mathrm{~d}, \quad \mathrm{C}-4^{\prime}\right), \quad 62.3 \quad\left(\mathrm{t}, \quad \mathrm{C}-5^{\prime}\right) ; \quad$ NMR $\delta_{\mathrm{H}}\left(\mathrm{CD}_{3} \mathrm{OD}\right): 7.82(1 \mathrm{H}, \mathrm{d}, J=1.3 \mathrm{~Hz}, \mathrm{C} 6 \mathrm{H})$, $5.89\left(1 \mathrm{H}, \mathrm{D}, J=4.6 \mathrm{~Hz}, \mathrm{Cl}^{\prime} \mathrm{H}\right), 4.19(1 \mathrm{H}, \mathrm{d}$, $\left.J=4.6 \mathrm{~Hz}, \mathrm{C} 2{ }^{\prime} \mathrm{H}\right), 4.15(1 \mathrm{H}, \mathrm{d}, J=4.7 \mathrm{~Hz}$, $\left.\mathrm{C}^{\prime} \mathrm{H}\right), 4.00\left(1 \mathrm{H}, \mathrm{m}, \mathrm{C} 4^{\prime} \mathrm{H}\right), 3.81(1 \mathrm{H}, \mathrm{d}$, $\left.J=3.1 \mathrm{~Hz}, \mathrm{C} 5^{\prime} \mathrm{H}\right), 3.77(1 \mathrm{H}, \mathrm{d}, J=3.1 \mathrm{~Hz}$, $\left.\mathrm{C}^{\prime} \mathrm{H}\right), 1.88(3 \mathrm{H}, \mathrm{d}, J=1.3 \mathrm{~Hz}, \mathrm{C} 5-\mathrm{Me})$.

\section{The effect of temperature on the reaction rate}

The reaction was carried out at $40 \sim 80^{\circ} \mathrm{C}$ (Fig. 2). Up to $70^{\circ} \mathrm{C}, 5 \mathrm{MU}$ and hypoxanthine were synthesized with time, but heat denaturation was observed at $80^{\circ} \mathrm{C}$. This showed that the enzymes were heat stable.

\section{The effect of the phosphate concentration}

As shown in Fig. 3, the formation of hypoxanthine increased with the concentration of phosphate, but the formation of $5 \mathrm{MU}$ remained almost the same. Without potassium phosphate, the reaction did not proceed. 5MU was also formed in sodium phosphate buffer, in place of potassium phosphate buffer (data not shown). Thus, phosphate is necessary for this reaction.

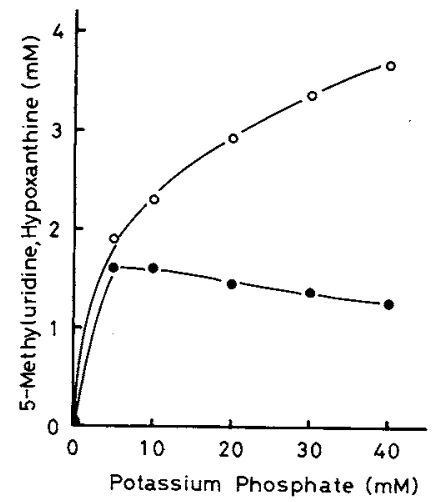

Fig. 3. Effect of the Phosphate Concentration.

Reaction mixtures containing $20 \mathrm{~mm}$ inosine, $20 \mathrm{~mm}$ thymine, $50 \mu \mathrm{l}$ of crude enzymes and various concentrations of potassium phosphate $(\mathrm{pH} \mathrm{7.0)}$, in a total volume of $1 \mathrm{ml}$, were incubated for $1 \mathrm{hr}$ at $65^{\circ} \mathrm{C}$. $\mathrm{O}$, hypoxanthine; , 5-methyluridine.

Table III. REACTION OF RIBOSE-1PHOSPHATE AND BASES

Reaction mixtures, containing $20 \mathrm{~mm}$ ribose-1phosphate, $20 \mathrm{~m} \mathrm{M}$ base, $20 \mathrm{~mm}$ potassium phosphate and $25 \mu \mathrm{l}$ of acetone-treated enzymes, in a total volume of $250 \mu \mathrm{l}$, were incubated at $60^{\circ} \mathrm{C}$.

\begin{tabular}{llc}
\hline \multirow{2}{*}{ Added base } & \multicolumn{2}{c}{$\begin{array}{c}\text { Nucleoside formed } \\
\text { (inosine* or 5-methyluridine }\end{array}$} \\
\cline { 2 - 3 } & \multicolumn{1}{c}{$15 \mathrm{~min}$} & $30 \mathrm{~min}$ \\
\hline Hypoxanthine & $1.86 \mathrm{~mm}^{*}$ & $3.40 \mathrm{~mm}^{*}$ \\
Thymine & $2.47^{* *}$ & $4.48^{* *}$ \\
\hline
\end{tabular}

Reaction of ribose-1-phosphate and bases

Ribose-1-phosphate and thymine or hypoxanthine were incubated with the crude enzymes, respectively. The corresponding nucleosides were formed (Table III).

A. solution containing $20 \mathrm{~mm}$ inosine and $20 \mathrm{~mm}$ potassium phosphate was incubated with the crude enzymes for $6 \mathrm{hr}$ at $65^{\circ} \mathrm{C}$. Ribose-1-phosphate was detected in this solution by HPLC.

\section{Heat stability of the enzymes}

The heat stabilities of the enzymes were investigated at $63^{\circ} \mathrm{C}$ and $70^{\circ} \mathrm{C}$ (Fig. 4). The half-lives of the enzymes synthesizing $5 \mathrm{MU}$ were $400 \mathrm{hr}$ and $14 \mathrm{hr}$, respectively. On the 


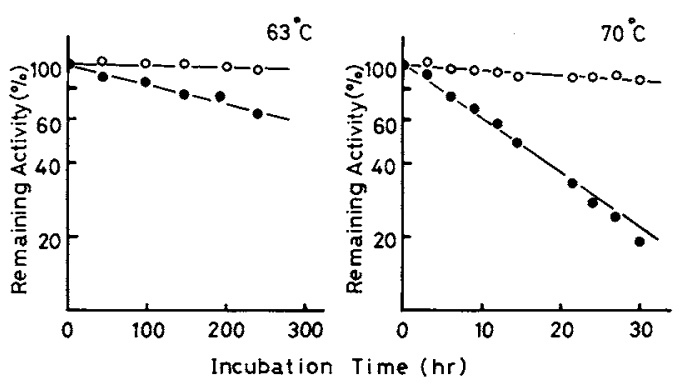

Fig. 4. Heat Stabilities of the Enzymes.

The crude enzymes were kept with $1 \mathrm{~mm}$ inosine, $1 \mathrm{~mm}$ thymine and $20 \mathrm{~mm}$ potassium phosphate $(\mathrm{pH} 7.0)$ at $63^{\circ} \mathrm{C}$ and $70^{\circ} \mathrm{C}$, respectively. The remaining activity was assayed by a standard method. $O$, PUNP activity;, PYNP activity.

other hand, the half-lives of the enzyme for hypoxanthine were $7200 \mathrm{hr}$ and $150 \mathrm{hr}$ at $63^{\circ} \mathrm{C}$ and $70^{\circ} \mathrm{C}$, respectively. The half-lives of the enzymes synthesizing 5MU and hypoxanthine were different, so the ribosyl transfer reaction was considered to be carried out by two kinds of enzymes.

\section{Discussion}

As the result of screening of many thermophiles, we found that B. stearothermophilus JTS 859 produced thermostable enzymes that synthesize $5 \mathrm{MU}$ from inosine and thymine in the presence of phosphate. B. stearothermophilus JTS 859 grew rapidly and its enzymatic activity also changed rapidly, as shown in Fig. 1. It was considered that these are characteristics of a thermophile. Due to the rapid growth of many thermophiles, only $4 \mathrm{hr}$ cultured cells might show the enzymatic activity on screening.

It was considered that this ribosyl transfer reaction was carried out by a combination of a purine nucleoside phosphorylase (PUNP) (EC 2.4.2.1) and a pyrimidine nucleoside phosphorylase (PYNP) (EC 2.4.2.2), due to the following facts. First, phosphate was necessary for the reaction. Second, the reaction of ribose-1phosphate and bases with the crude enzymes resulted in the formation of the corresponding nucleosides. The incubation of inosine and potassium phosphate with the crude enzymes yielded ribose-1-phosphate. Third, the heat stability of the enzyme synthesizing hypoxanthine was different from that of the enzyme synthesizing $5 \mathrm{MU}$. Therefore, it is considered that this reaction consists of the two ribosyl transfer reactions shown above, i.e., Eq. (1) and (2).

The optimal temperature for the reaction was $70^{\circ} \mathrm{C}$. Even at $80^{\circ} \mathrm{C}, 5 \mathrm{MU}$ and hypoxanthine were synthesized within $1 \mathrm{hr}$, but the enzymes were apparently denatured at this temperature. Regarding the PUNP, it was stable at $70^{\circ} \mathrm{C}$, i.e., above the optimal growth temperature $\left(62 \sim 66^{\circ} \mathrm{C}\right)$, although the phenomenon of that a thermophile enzyme is rapidly inactivated at a slightly higher temperature than the optimal growth temperature has been shown to be characteristic of several thermophile enzymes. ${ }^{11)}$ The half-lives of PYNP and PUNP were $400 \mathrm{hr}$ and $7200 \mathrm{hr}$ at $63^{\circ} \mathrm{C}$, respectively. It is interesting that their heat stabilities were very different, although they were derived from the same strain and their functions are similar. As for a purine nucleoside phosphorylase and a uridine phosphorylase derived from a mesophile, Enterobacter aerogenes, the half-lives at $60^{\circ} \mathrm{C}$ were about $170 \mathrm{hr}^{7}{ }^{7}$ The enzymes from the present thermophile are extremely stable compared to the above mentioned ones from a mesophile. As for PYNP derived from a thermophile, $B$. stearothermophilus NCA10, it was stable at $60^{\circ} \mathrm{C}$ for $1 \mathrm{hr}$ but was denatured at $70^{\circ} \mathrm{C}$ for 1 hr. ${ }^{8)}$ The PYNP from B. stearothermophilus JTS 859 is more stable than the PYNP from $B$. stearothermophilus NCA10. The PUNP produced by B. stearothermophilus JTS 859 is the most themostable nucleoside phosphorylase, as far as we know. Due to their heat stabilities, PUNP and PYNP produced by $B$. stearothermophilus JTS 859 are useful for practical application, especially as immobilized enzymes.

\section{References}

1) MacNutt, Biochem. J., 50, 384 (1952).

2) T. Sakai, T. Tochikura and K. Ogata, Agric. Biol. Chem., 29, 742 (1965). 
3) J. J. Scocca, J. Biol. Chem., 246, 3691 (1971).

4) J. C. Lee, K. Hammer-Jespersen and M. Schwartz, Eur. J. Biochem., 75, 217 (1977).

5) W. E. Razzell and P. Casshyap, J. Biol. Chem., 239, 1789 (1964).

6) J. D. Stocker, C. Camber and R. E. Parks, Jr., Biochemistry, 19, 102 (1980).

7) T. Utagawa, H. Morisawa, S. Yamanaka, A. Yamazaki, F. Yoshinaga and Y. Hirose, Agric. Biol. Chem., 49, 3239 (1985).
8) P. P. Saunders, B. A. Wilson and G. F. Saunders, $J$. Biol. Chem., 244, 3691 (1969).

9) A. Fichter, ed., Advances in Biochemical Engineering/Biotechnology, 28, 69 (1983).

10) P. H. A. Senath, ed., "Bergey's Manual of Systematic Bacteriology," Vol. 2, Williams and Wilkins, Baltimore, 1986, p. 1135.

11) Champbell, L. L. and Pace, B., J. Appl. Bacteriol., 31, 24 (1968). 